\title{
INOVAÇÕES E VIÉSES IDEOLÓGICOS DA EDUCAÇÃO DE JOVENS E ADULTOS: UMA INCURSÃO HISTÓRICA A PARTIR DE UM RELATO DE SUPERVISÃO PEDAGÓGICA DO MEB*
}

\author{
Carlos Angelo Meneses Sousa, \\ da Universidade Católica de Brasília
}

\begin{abstract}
Resumo: A década de 1960 é indubitavelmente um marco para a História da Educação de Jovens e Adultos no Brasil. Nesse período, foram criados diversos movimentos de educação e cultura popular. Dentre eles, o Movimento de Educação de Base (MEB) se destacou e é o único que continua a existir. Há uma vasta literatura sobre o MEB, todavia há poucos trabalhos e pesquisas sobre a sua presença e atuação no Piauí. Nesse estado, houve algumas peculiaridades que tornaram sua ação um tanto diferente de outras experiências comumente apontadas na literatura acadêmica. Com base em fontes documentais primárias, especialmente da década de 1960, a pesquisa discorre sobre a prática educativa desenvolvida na Educação de Jovens e Adultos do MEB, no Piauí, a partir de um relato de supervisão pedagógica destacando suas inovações e viéses ideológicos.

Palavras-chave: Educação de Jovens e Adultos. MEB. História da Educação. Política.
\end{abstract}

No final dos anos 50 e início dos anos 60 do século XX, a conjuntura mundial se apresentava sob a égide da prosperidade e confiança. As duas grandes potências de então, os Estados Unidos e a União Soviética, acenavam para um "degelo" em suas relações. Passadas as mazelas da II Guerra Mundial, a economia crescia e havia um otimismo social. Os conhecimentos científicos e os avanços tecnológicos intensificavam as informações, impulsionavam os transportes e multiplicavam o poder de produção.

* Artigo recebido em 13/04/2011 e aprovado em 11/08/2011. 
Vivia-se um momento ímpar de alastramento de uma nova visão de política nas relações sociais e na cultura. Projetos e novas utopias eram tecidos no imaginário coletivo. Como exemplo de toda essa efervescência temos a emancipação sexual, o rock, a revolução Cubana (1959), a China de Mao-Tsé-Tung, o Concílio Vaticano Il (1962-1965) e as lutas pela independência nas colônias do Terceiro Mundo.

Essa efervescência também se fez presente na realidade brasileira. Houve aqui, no entanto, elementos históricos e sociais que deram uma peculiaridade a tal conjuntura. Vivíamos o fim do "pacto populista" (19451964) e desencadeavam-se movimentos políticos e sociais de grande mobilização, imbuídos do grande afã de transformação social. A educação era considerada instrumento indispensável na transformação das mentalidades e das estruturas (SEMERARO, 1994, p. 19-23).

É nesse contexto que emergem os movimentos de educação e cultura popular como o Centro de Cultura Popular (CPC), o Movimento de Cultura Popular (MCP) de Recife, o Movimento de Educação de Base (MEB), o movimento "De pé no chão também se aprende a ler" de Natal e o Sistema Paulo Freire. Eles apresentavam como horizonte teórico a ênfase no culturalismo, na construção de uma democracia acima das classes e nas etapas do progresso numa concepção histórica ascendente da realidade (PAIVA, 1980, p. 144).

Entre esses movimentos destacamos o Movimento de Educação de Base (MEB). Fundado pela Conferência Nacional dos Bispos do Brasil (CNBB), sua mentora e organizadora, e o Governo Federal, seu financiador, o MEB tinha o objetivo de realizar a alfabetização de adultos, no contexto de um programa de educação básica, através de escolas radiofônicas implantadas no interior e nas regiões menos desenvolvidas do Brasil.

$\mathrm{Na}$ verdade, o interesse do Governo era ampliar o contingente eleitoral, restringindo assim o poder das oligarquias rurais e manter um controle ideológico sobre as massas rurais. À Igreja interessava expandir sua tradicional preocupação com a educação, assegurar seu prestígio, sua influência religiosa e opor-se à avançada do comunismo (WANDERLEY, 1984, p. 49-50).

Logo nos primeiros anos, os objetivos iniciais do MEB foram sendo modificados por seus agentes e coordenadores, na maioria leigos, que na prática dirigiam o movimento. De uma finalidade basicamente alfabetizadora passou-se para uma educação que incentivava a consciência crítica e a politização, a valorização da cultura popular, a autonomia das comunidades, a organização e a animação popular. Tudo isso, em parte, se deu pelo contato direto dos quadros do MEB com a difícil realidade vivida pelo campesinato, o 
contato com as forças de esquerda e o próprio movimento inaugurado com o Concílio Vaticano Il que arejava a Igreja Católica para as questões sociais.

O MEB tornou-se um dos mais expressivos e criativos movimentos de educação popular da época. Inovou e assumiu uma nova e diferente ação da Igreja Católica no campo educacional que era, até então, predominantemente conservadora e defensora dos interesses privatistas como podemos ver no episódio da Lei de Diretrizes de Base (LDB) de 1961. A tensão do caráter conservador da Igreja Católica e essa nova vertente libertadora no seu seio será permanente na história do MEB.

O Golpe Militar de 1964 e seus desdobramentos interferiram gravemente em todos os movimentos de educação e cultura popular, perseguindo-os e reprimindo-os até o seu desaparecimento. No caso do MEB, apesar da forte perseguição e do fechamento de alguns de seus departamentos, o seu vínculo com a CNBB o protegeu do desaparecimento completo. Isso lhe custou a modificação de sua orientação político-pedagógica.

\section{O MEB NO PIAUÍ}

A fundação do MEB no Piauí se deu, oficialmente, em 1962, após terem sido dados os primeiros passos para tanto, em 1961, com a montagem de uma emissora de rádio voltada especificamente para a educação - a Rádio Pioneira de Teresina - e a realização de um treinamento para capacitação de pessoal e formação da equipe do sistema. Nas palavras do seu primeiro coordenador, Padre Isidoro Pires de Souza, no discurso inaugural do programa do MEB, podemos observar a relevância dada ao pioneirismo da emissora de rádio para a educação no estado do Piauí, mormente através do MEB; vejamos algumas partes deste discurso:

Vivemos um momento histórico para o Piauí. Rádio Pioneira de Teresina mais uma voz que se espraiando de campina em campina, ecoando de quebrada em quebrada [...] uma voz autorizada em prol da educação e do povo. O resultado de uma batalha insana, travada, desde o início, com os olhos voltados para o Movimento de Educação de Base. Sim, senhores ouvintes, o MEB, neste instante, tem o justo orgulho de ter sido o móvel principal da luta gloriosa por mais uma emissora para o Piauí. [...] O nosso pioneirismo alcança outro campo que não o da antiguidade. O nosso pioneirismo está na linha da Educação de Base, campo ainda inexplorado na radiofonia piauiense. Pioneirismo na tarefa urgente de levar luz a tantas inteligências ainda obnubiladas pelas trevas da alienação aos problemas mais agudos da nacionalidade, campo profícuo à germinação de ideias e ideologias alheias e até adversas à consciência brasileira. Pioneirismo no que concerne à veiculação de prin- 
cípios atingentes ao homem todo, este composto maravilhoso de alma e corpo, detentor de uma destinação eterna e transcendente. Pioneirismo na tarefa altíssima de libertar inteligências moças criminosas unicamente pelo crime de não saber ler. (SOUZA, 1962, p. 1)

Sob os auspícios de um otimismo pedagógico, de uma apologia da educação como a grande solução para os problemas do País, convoca os analfabetos para despertar e aprender a ler:

despertai, gigantes, ao som desta clarinada ! Despertai, gigantes dos campos e chapadas! Despertai, homens das fazendas, dos sítios e dos canaviais. É uma nova era que desponta. Nunca é tarde para aprender a ler. "Mais vale uma esperança tarde que um desengano cedo". Cansados talvez estais das lides ingratas do mourejar quotidiano e velhos, certamente, pelos anos que arcais, mas sois portadores de uma inteligência descansada e moça ainda nas fulgurâncias mais radiosas e nos seus mais ardentes lampejos. A paradoxal sociedade campesina é ainda este fabuloso gigante adormecido pela letargia do analfabetismo; ou mais paradoxalmente, é um aglomerado de pigmeus embuçados pela máscara fatídica da ignorância e da alienação. Ou com mais propriedade diríamos, o Prometeu acorrentado da fábula, capaz de todos os heroísmos, desde que alguém lhe venha romper os malfadados grilhões. (SOUZA, 1962, p. 2).

Apesar desse início discursivo eufórico, as atividades radiofônicas sofreram grande dificuldade pela não transmissão do programa da emissora em muitas localidades. Tal situação motivou a equipe organizadora do MEB a desenvolver um trabalho mais diligente com os monitores, enquanto era aguardada a solução desse problema técnico. Já que era considerado atrasado em relação a outros sistemas do MEB, foi preciso apressar-se o máximo possível. Quando o problema técnico fosse resolvido, já teriam um corpo de monitores habilitados para o trabalho. Isso fez com que se voltassem mais, em sua ação, para o contato direto com as comunidades rurais. Esse fato tornou a experiência do MEB no Piauí diferente das demais, e por essa razão, mais adiante centrarei a minha exposição nesse trabalho de contato com as comunidades por considerá-lo, inclusive, um bom exemplo da experiência de Educação Popular, especialmente de Alfabetização de Jovens e Adultos, desenvolvido pelo MEB nesta época.

Vale ressaltar que o MEB no Maranhão também apresentou essa particularidade, embora de uma forma diferenciada, já que lá, praticamente, não foi desenvolvido um trabalho com a modalidade de escolas radiofônicas como nos outros estados da federação em que o MEB atuava. O motivo se deu pela implantação tardia da Radio Educadora do Maranhão Rural (REMAR), em 
junho de 1966, cinco anos após a fundação do MEB maranhense. Entretanto, em virtude disso, criaram a notável experiência da Animação Popular. Para maiores detalhes sobre a experiência no Maranhão, vale conhecer a pesquisa de Raposo (1985).

A fim de se ter uma visão quantitativa da atuação do MEB no Piauí, nesses anos, segundo Duarte (1973, p. 7-9), em 1962 o número de municípios atingidos era de 3, passando para 15 em 1963; 22 em 1964; 21 em 1965 e 20 em 1966. Quanto ao número de escolas radiofônicas, em 1962 havia 33 que atingiam 820 alunos; em 1963 somava 139 com 2.575 alunos; em 1964 totalizava 288 com 6.675 alunos; em 1965 somava 209 com 3.256 e em 1966 perfazia a quantidade de 187 escolas radiofônicas com 1.457 alunos. O número de membros da equipe do MEB no Piauí somava o total de 16 no seu início até 1964, tendo caído consideravelmente no ano seguinte para menos da metade, isto é, 7 membros e 6 membros em 1966. Uma leitura dos dados numéricos indica um crescimento nas atividades e no público atingido na sua origem até 1964. O Golpe Militar, neste ano, indubitavelmente repercutiu fortemente no MEB, em todos os seus estados, declinando suas atividades.

\section{A prátICA PEDAGóGICA do MEB-Piauí}

O MEB entendia o processo de "Animação Popular(AnPo)" como aquele "trabalho animado por elementos populares" em que o próprio povo assumisse processualmente o movimento educacional por ele desencadeado (MEB, s/d, p. 26).

Após a escolha da área geográfica de atuação, as equipes do MEB passaram a desenvolver as seguintes fases do processo de Animação Popular: o estudo de área, a identificação e o treinamento de lideranças e a supervisão e assessoramento.

É bom observar que, desde o início dessa ação, essas fases se interpenetram e não há um momento só para o desencadeamento ou conclusão dela. O estudo de área visava obter subsídios que possibilitassem um conhecimento mais preciso das realidades econômica, social e política das comunidades em que as equipes pretendiam atuar. Para tanto, faziam contato com as autoridades municipais e com as bases dessas localidades.

Cônscios, desde o início, de que o trabalho da Animação popular deveria ser assumido pelas próprias comunidades, os agentes do MEB, baseados no princípio de autonomia, buscavam o protagonismo das organizações populares. Aí se insere a sua atenção sistemática em detectar e despertar lideranças da própria comunidade para que pudessem ir assumindo em formação a condução da Animação Popular, pois 
um trabalho assumido e encabeçado por elementos do próprio meio tem, naturalmente, maiores possibilidades de acolhida e aceitação por toda a comunidade. Tais elementos têm, normalmente, maior facilidade de expressão, compreensão, comunicação, além de uma maior percepção dos problemas e das aspirações de todos. (MEB, 1965, p. 5)

Tudo isso era feito processualmente, e tais lideranças identificadas eram constantemente desafiadas a assumir coordenações de atividades e reuniões com a comunidade a fim de que fossem reconfirmadas em sua liderança perante a comunidade e, concomitantemente, testada sua real capacidade de liderança. Digo reconfirmadas, porque era a própria comunidade que indicava sua liderança e ao MEB cabia ajudar a comunidade na reflexão destes critérios para uma boa escolha: lealdade, autenticidade, facilidade de comunicação, possibilidade de estabelecer um verdadeiro diálogo com a comunidade, sensibilidade e identificação suficientes para compreender e sintetizar a problemática da comunidade e uma atuação segura e autêntica (MEB, 1965, p. 8).

Apesar de toda essa preparação, registra-se em várias experiências do MEB, em diferentes estados, que nem sempre se obteve sucesso com tal escolha pois, em algumas comunidades, era muito difícil romper com as escolhas baseadas "nos donos do lugar" ou somente naqueles que se expressavam com destaque.

Em um segundo momento, o MEB propiciava os treinamentos que, além do objetivo de instrumentalizar as lideranças com o domínio de técnicas necessárias às atividades de coordenação de grupos, reuniões e debates ou de técnicas de comunicação, visavam, sobretudo, a"conscientizá-los da realidade brasileira" na expressão do documento já citado da Animação Popular(AnPo). Tais treinamentos eram realizados numa perspectiva de continuidade e aprofundamento, respeitando a caminhada da própria comunidade. Outra característica, senão a principal, era que esses treinamentos eram direcionados para um engajamento específico. O conteúdo e a metodologia utilizados tinham a preocupação de adequação à realidade dos participantes, na maioria analfabetos, a fim de que fossem processualmente assenhoreando-se do que experienciavam e refletiam. Daí não cair na tentação de sobrecarrega de conteúdos num só treinamento e a necessidade da própria equipe do MEB elaborar materiais, na sua maioria com ênfase visual. Após os treinamentos, os parâmetros de exigência em relação às lideranças eram ter um mínimo de conscientização, representatividade, autocrítica, capacidade de trabalho em grupo, iniciativa, agilidade mental, responsabilidade, objetividade e qualidades específicas para cada ação (MEB, 1965, p. 6-9). 
A supervisão era desenvolvida por meio do acompanhamento e da assessoria às comunidades onde se desenvolvia a AnPo. A assessoria era compreendida como a participação de técnicos em todas as etapas e fases da AnPo, variando de intensidade de acordo com a necessidade das comunidades, almejando seu decréscimo na medida em que elas pudessem desenvolver autonomamente a AnPo. A supervisão consistia em

trocar ideias, informar sobre o que ocorre no País e no mundo, coordenar os trabalhos com outras entidades cuja validade seja comprovada; refletir com os líderes sobre o trabalho feito, os novos planos e o resultado das experiências concretas e mudanças na comunidade. (MEB, 1965, p. 9)

A atividade de supervisão era o instrumento mais importante para o crescimento e a avaliação do processo, pois era por meio dela que seus assessores podiam perceber continuamente o desenvolvimento, o aproveitamento e a repercussão da programação educativa nas comunidades. Havia, assim, a potencialização tanto da comunidade como da própria equipe do MEB no conhecimento da realidade e do aprimoramento de seus planos. Além do assessoramento direto às comunidades, especialmente aos seus líderes nos encontros, treinamentos e nas reuniões, havia também o assessoramento indireto através de correspondências, material de estudo, publicações e outros. Nessa última modalidade, havia também, a assessoria por meio de um programa radiofônico.

Para sabermos como essa atividade de supervisão e assessoramento se deu concretamente no cotidiano da equipe do MEB no Piauí, vamos ler alguns trechos de relatos elaborados por assessoras da Equipe do MEB-Piauí, em 1963.Nesses trechos, vale observar: que tipo de relato utilizavam? Que elementos consideravam? Por quê? Percorrer os relatos com esse olhar investigativo poderá nos ajudar a reconstruir as intenções da narrativa. $\mathrm{O}$ olhar aqui é de quem quer "olhar com os olhos do narrador", não definindo completamente, a priori, o que vai extrair do olhar, descobrindo assim, antes de tudo, "a lógica do seu olhar", que muitas vezes desconsidera e/ou secundariza "o olhar/lógica original do narrador" e as condições de sua produção. Aqui não há intenção de neutralidade e sim de consciência da intervenção interpretativa que todo pesquisador faz em qualquer objeto de pesquisa.

Passemos, então, ao relatório de supervisão do MEB-Piauí, no qual, apresentavam seus objetivos sob a forma de uma prescrição para o exercício dessa atividade:

Supervisão - avaliar e aprofundar o trabalho rápido; 
- conhecer a atuação do Monitor, sua relação com os alunos e a influência que está exercendo na comunidade;

- conhecer as impressões dos moradores sobre as Escolas Radiofônicas.

- Aprofundar o contato:

- saber o que o povo quer;

- levar informações práticas;

- esclarecer dúvidas ideológicas em torno da linha do MEB;

- conhecer os recursos da comunidade;

- descobrir os valores do povo;

- descobrir líderes, tendo em vista o trabalho de animação popular. (SILVA e GUIMARÃES, 1963, p. 1)

A duração dessa supervisão foi de 10 dias, de 17.05.1963 a 26.05.1963. Algo que chama a atenção no relato, quase como um diário de campo, é a busca de ver, observar os diversos aspectos da vida, do cotidiano da comunidade e de seus membros. Vale destacar aqui a atenção pela dimensão lúdica do lazer, das festas, mesmo que às vezes contaminada por um tom moralista e contraditório, e brincadeiras da localidade que ocupam bons trechos do relato; vejamos:

Também aprendemos algumas cantigas e brincadeiras, das quais trouxemos algumas gravadas em fita magnética para serem apreciadas pela equipe do MEB-PI [...] a recreação deu ensejo também para a descoberta de líderes naturais. [...] Os jovens de Agricolândia não têm em que empregar seus momentos de folga. Vivem parados. Nunca se encontram num ponto para conversar ou divertir-se. A diversão habitual para eles são os bailes. Todo sábado há festas. O namoro é tido como passatempo; namoravam por namorar, do que muitas vezes resultam casamentos apressados e fadados à desventura. Podemos constatar que uma aspiração mais forte daquela juventude é a recreação. Outra aspiração: aprender a ler, não propriamente com fim de cultivar o espírito, mas para poder ler romances populares (de feira) e revistas de aventuras amorosas. Os jovens não têm iniciativas por si mesmos de realizar certas atividades, como quadrilhas, leilões, bingos e prendas. A quadrilha, por exemplo, é animada só quando se encontra na localidade a filha do prefeito, que dirige os ensaios e preparativos da dança. Então a festa conta com a participação de moças e rapazes, porém, na ausência dessa pessoa, nada se realiza nesse sentido. Fica todo mundo a lamentar, ninguém toma a frente. (SILVA e GUIMARÃES, 1963, p. 4)

Todo ano há um novenário que antecede o dia da festa do santo do lugar. Cada noite pertence a um tipo de noitantes: dia das moças e rapazes é o mais mole, conforme depoimento. Não se reúnem para combinar nada e 
as coisas saem de qualquer jeito. Essa situação é fruto daquela sociedade. Os pais, os mais velhos, acreditam que moça deve ficar em casa, sob a vista dos pais: "cobra que muito anda leva cacetada". Segundo eles, só os rapazes podem fazer tudo, pois "neles nada pega". (p. 5)

Também visitamos dois bailes, para ver como o povo se diverte. Soubemos então que há dificuldade em arranjar tocador no local [...] Para os bailes, que são realizados todos os sábados, é contratado tocador de fora, por preço geralmente muito alto. Os bailes não têm sentido educativo. Os homens vão mais para beber e jogar(dinheiro) que mesmo divertir-se. Espalhadas pelo terreiro da festa, há grande número de bancas de jogo. As festas vão até pela manhã e dificilmente elas acabam sem uma rixa entre os dançarinos. (p. 7)

O contato direto e pessoal dos agentes do MEB, feito com visitas domiciliares e conversas informais, certamente os ajudava a imiscuir-se na realidade das famílias da localidade a ponto de virem à tona, com detalhes, elementos distintos dessa realidade que iam desde o modo como a economia doméstica se desenvolvia, sobressaindo nesse processo o papel da mulher, ao modo como se dava a comercialização na pequena cidade:

Ainda na tarde de 17 - chegada a Agricolândia - a equipe iniciou o trabalho de visitas domiciliares [...] No dia seguinte, continuamos o trabalho de visitas. Para isso a equipe se dividiu, cada elemento formou um grupo constituído de rapazes e moças da localidade e saiu de casa em casa, durante toda a manhã. Nessas visitas ia-se conhecendo a realidade daquele povo, por meio de conversas informais. Na oportunidade, fazia-se o convite para a reunião da noite, o qual teve boa aceitação.

Apresentamos o resultado obtido numa das entrevistas, que retrata mais ou menos a situação geral das demais famílias da localidade: família relativamente numerosa, com dificuldade para manter-se, pois o que ganha está longe de atender às necessidades da casa. A esposa, em consequência, é levada a desenvolver várias atividades dentro e fora do lar, para ajudar no sustento dos filhos. Por exemplo: o fabrico manual do labirinto e da renda de almofada. Às vezes, nas festas vende frito, café, abóbora cozida etc.; além do trabalho doméstico há o da roça. Tudo isso sofrendo as inúmeras dificuldades, como falta de terra, no caso da lavoura; tratando-se do labirinto, além da dificuldade na aquisição do material empregado - fio - ainda enfrenta o problema da venda. $O$ comércio lá é muito pequeno e os centros maiores não valorizam bastante o produto. O lucro não compensa e sempre há prejuízo.

Nos dias de baile(aos sábados), aquela senhora costuma arrumar uma banquinha no sereno da festa, onde vende fritura e bolos, cujo lucro é pouco e com o perigo de não vender toda a mercadoria, devido à concorrência (nesse 
dia há muitas banquinhas como a dela) e mesmo pela falta de dinheiro dos dançarinos que, por sua vez, já gastam com cotas e bebidas.

O marido, ao que se pôde notar, não tem possibilidades econômicas, nem de trabalho, suficientes para suprir as necessidades do lar. Trabalha de roça e paga renda muito alta.

Aquela família tem, fora todas as dificuldades, problemas gerados pela falta de formação familiar. Duas filhas do casal, sem nenhuma orientação, casaram-se muito cedo - imaturas, portanto, para as responsabilidades que o estado exige, o que resultou em pouco tempo, no desenlance, de consequências graves: maridos deixaram o lar com intenção de conseguir emprego fora(Brasília) e não voltaram, ficando as esposas abandonadas, sem apoio e ocupação definida - uma ameaça para a integridade moral. (SILVA e GUIMARÃES, 1963, p. 5-6)

Não há mercado e uma vez por semana, em dia não fixado, fazem uma precária. Nos sábados matam um boi que, para ser vendido, passa geralmente todo o dia exposto. $O$ açougueiro costuma então tomar um chifre para avisar que a carne fresca está à venda. (p. 8)

Além desses relatos mais voltados para os aspectos microculturais da realidade, temos também parte do relatório descrevendo, em muitas linhas, tanto a situação educacional, religiosa, política e econômica da localidade, como também as condições de saúde.

Sobre a situação educacional, as autoras afirmam:

É muito ruim. Há uma única escola, em condições de funcionamento precário, com professor leigo para criança. Quem pode estudar fora sai e não volta, geralmente. Quem não tem possibilidade de fazer isso continua entregue à ignorância. Nesse caso encontra-se a grande maioria. E o mais grave é que o povo, e até as autoridades, não se preocupam com o problema. A comunidade está como que adormecida para o valor da educação. A grande maioria dos habitantes é analfabeta. (p. 7)

Quanto à situação religiosa, descrevem mais alongadamente que:

não há padre na localidade. Missa só duas vezes por ano, em julho e dezembro. Há, nessas ocasiões, novenas e festejos, com leilões e outras iniciativas com fins lucrativos. Costuma-se também festejar o mês de maio, rezando diariamente o terço. O protestantismo tem facilidade de acesso, devido mesmo à falta de assistência religiosa. Algumas pessoas que praticam a religião o fazem sem convicção. Podemos verificar o pouco valor dado ao batismo, por exemplo. Encontramos uma família cujos filhos são todos pagãos e seus pais, mesmo assim, vão à missa, confessam-se; muitos adiam a data do batismo dos filhos, esperando pelos padrinhos que vão chegar quando 
puderem ou que possam fazer festa, inclusive traje. Outra coisa: gente procura a macumba ou o espiritismo. Também não dão ao casamento seu verdadeiro sentido cristão, casam só no civil. Inúmeros maridos abandonam as famílias, sem nenhuma preocupação com o destino dos filhos e da esposa. Pode-se constatar a prática do "benzimento", de certas superstições. O sofrimento, a pobreza, a miséria, até, o povo admite, que sejam fruto da vontade de Deus e por isso não adianta lutar: conformismo. Conversando com várias pessoas, várias mesmo, podemos sentir que acreditam muito no destino, na fatalidade. (SILVA e GUIMARÃES, 1963, p. 7)

A respeito das condições de higiene, descrevem:

Não foi possível descobrir a existência de doenças características da região, a não ser, na época da surpervisão, muita "pira". Talvez pela falta de asseio corporal e do vestuário. A alimentação, de modo geral, é muito fraca. Não se come carne nem toma-se leite. Verdura não se adota na alimentação e não encontramos um canteiro, sequer, onde fossem cultivados a cebola, o coentro, o tomate etc. Motivos de tudo isso: ignorância e pobreza. A comunidade inteira luta com muita dificuldade para adquirir água. Não há olho d'água ou riacho, que possam servir a todos. Bebem água de poços e estes são particulares. O município mesmo não tem um só para utilidade pública. Água ali é um problema. Daí porque há muita sujeira, ausência da prática de banho e limpeza do vestuário. Não há fossa em nenhuma das casas visitadas. Os dejetos são lançados no fundo dos quintais e logo devorados pelos bichos. Há animais criados dentro de casa; o povo a cuspir no chão, crianças com piolhos e bicho de pé. (p. 7-8)

A situação política é apresentada da seguinte forma:

Até bem pouco tempo Agricolândia era povoado. Passou a ser cidade em dezembro de 1962 com prefeito nomeado. Atualmente o povo está se preparando para as primeiras eleições, em outubro próximo. Verificamos que há certa tendência em passar a administração para outras mãos. O povo não parece satisfeito com o atual. Como o prefeito era em função, não pode ser candidato, o povo não está querendo votar nem mesmo em candidato apontado por ele. Não se pode afirmar que isso possa acontecer, pois o povo se prende muito ainda ao chamado "voto de cabresto". (p. 8)

O aspecto econômico é descrito a partir do título "Trabalho e Produção", em que se diz:

há uma desproporção entre o trabalho e a produção. A população constituise, na maioria, de pequenos agricultores, trabalhando em terras arrendadas, que não são base da produção. Não recebem ajuda do proprietário e não são assegurados. A principal produção é o arroz, que só deve ser vendido 
ao proprietário, geralmente. Para beneficiar há uma usina do prefeito, que cobra vinte e cinco quilos por cada saca (o lavrador dá 85 quilos em casca e recebe 60 pilados). 0 empréstimo bancário não deu muito resultado: antes veio sacrificar muitos lavradores que, sem plano, não souberam manejar o dinheiro gastando com outras coisas e isso criou sérios prejuízos, de parte, tanto para o pequeno agricultor como para o proprietário[...] [sobre a Reforma Agrária] “há uma confusão generalizada. Ninguém entendeu ainda o sentido exato da Reforma. Os proprietários veem nela o maior dos absurdos e embora meio descrentes, achando que ela não virá, já estão deixando de adquirir mais terras e muitos pais já estão dando a cada filho seu quinhão. Por outro lado, os agregados estão satisfeitos e esperam, com alguns planos em mente, a bendita Reforma 'tomada das terras do rico pra dá aos pobres'. Necessário, pois, um trabalho de esclarecimento sobre o que é Reforma Agrária[...]". (p. 9)

Como arremate, sob o título de "Impressões", as duas relatoras afirmam:

O povo de Agricolândia, apesar das suas deficiências culturais e de meios, alcançou, de algum modo, o sentido da mensagem que a Supervisão Ihe quis levar. A Equipe, na realidade, não levou valores para a comunidade; porém, através de contato com o povo, levou-o a descobrir os valores: higiene, saúde, trabalho, recreação. Contamos com o apoio e a amizade dos moradores, o que tornou proveitosa a nossa atuação. A participação do povo nas atividades foi notável e concorreu para despertar naquela gente o interesse pela solução dos próprios problemas. Cada um parece ter começado a sentir o valor de sua colaboração no progresso e felicidade da comunidade. (p. 9-10)

O relato sobre as aulas radiofônicas é sequenciado com o título "Anotações de Supervisão" e dividido em subtítulos: "Ambiente da aula", "Aproveitamento" e "Sugestões". Nele, assim discorrem as autoras:

Todas as escolas da sede funcionam na casa do Monitor, em sala relativamente ampla, exceto a da Monitora Socorro Martins que não oferece acomodação. Assentos: bancos, cadeiras e tamboretes arranjados pelos próprios alunos. Geralmente os alunos escrevem sobre mesas. Alguns colocam nas pernas uma tábua sobre a qual escrevem.

lluminação: a querosene. Lamparinas individuais ou lamparinas de três bicos, suspensas no teto. Os alunos ali já estão se movimentando com leilões e rifas para adquirir o petromaz. Os alunos. Por ocasião da visita, a frequência estava muito baixa: 10 a 12 em média, dos quais só a metade assistiu à aula. De modo geral, ficaram muito parados durante as aulas, perdendo-se alguns nas explicações. Geralmente os alunos apresentam dificuldades em realizar a parte escrita. O homem do campo, por não ser acostumado a ouvir rádio, sente dificuldade em acompanhar a professora-locutora; escuta, mas não entende. Muitos justificam chegar atrasados pela distância das roças, uma 
légua das residências e perguntaram: Vocês não podem começar a aula mais tarde, às 7 horas ? Outra coisa: muitos alunos vão à escola sem material indispensável, por falta de recurso ou de quitanda. Alguns dos mais idosos pediram óculos à supervisão "que a vista está curta para ler".

Aproveitamento: os alunos estão satisfeitos com a ER e confiantes de que vão aprender. Os mais assíduos vão indo bem, já sabem mais ou menos o que foi ensinado. Os outros, os que faltam muito, vão bem atrasados e não querem mais voltar para a escola, achando não ter mais alcance para acompanhá-la. Um dos motivos mais fortes para a falta de frequência dos alunos, além da colheita do arroz, foi o boato de serem as escolas comunistas (a maioria caiu fora com medo). Monitor: os monitores da sede de Agricolândia em geral não exerceram influência no meio e a escola não está sendo foco de irradiação, de forma alguma. Porém, dentro da sala de aula, são ativos e de boa vontade no trabalho. Ajudam os alunos nas suas dificuldades, conversam sobre os assuntos da cultura popular(conforme suas possibilidades), não faltam à aula e são pontuais. Apresentam nível intelectual relativamente baixo e sua participação no trabalho sofre com isso. Dificuldades para eles: conseguir a colaboração dos alunos na compra de giz e pilhas e resolver o problema da frequência irregular dos alunos. Os monitores escrevem de forma errada o nome dos alunos, dos meses, da localidade etc. De modo geral, os alunos participam bem das brincadeiras realizadas; isso contribui para desembaraçar ou acabar com a inibição do grupo, naturalmente acanhado.

\section{Sugestões}

a) Intensificar o serviço de supervisão;

b) Não levar ao ar mensagem nenhuma, sem que a Equipe tenha conhecimento dela; muitas vezes o pensamento de um vai completar o trabalho de outros;

c) A Equipe produtora de programas, o quanto possível, deveria visitar as Escolas, a fim de apresentar aos alunos assuntos do interesse deles, na sua linguagem.

d) Sugerimos que as aulas sigam uma unidade metodológica e não sejam prejudicadas por falta de sistematização;

e) A supervisão, para surtir efeito, não pode ser feita com pressa, quanto mais puder se dar o contato da supervisão com a comunidade, melhor;

f) Apresentar um programa dirigido ao monitor, para ajudá-lo e formá-lo mesmo. Na maioria, os monitores estão completamente alheios à problemática do momento atual;

g) Tornar o noticiário mais vivo, dentro do interesse do aluno e do ouvinte do campo: fora as notas complicadas e sem interesse para eles, bem como o tom afetado com que está sendo apresentado; 
h) Apresentar qualquer programa que reúne em torno da ER a comunidade, para ver se se interessa e quer colaborar com a Escola;

i) Aproveitar para o programa ACONTECEU NAQUELES TEMPOS, temas da vivência do homem rural. (SILVA e GUIMARÃES, 1963, p. 10 -11)

Há uma grande riqueza de detalhes e um espantoso (e corajoso!) desnudamento das fragilidades e insucessos da ação educativa aqui enfocada que podem ser explorados nesse relatório. Deter-me-ei apenas em alguns com o fito de destacar aqueles que, entre outros, constituem importantes aspectos numa prática de educação popular considerada inovadora e seminal, sobretudo, para as experiências pastorais da Igreja Católica Progressista no período da ditadura militar pós-64 no Brasil (WANDERLEY, 1984; FÁVERO, 1984; MAINWARING, 1989) e também algumas críticas a aspectos desconsiderados ou secundarizados pelo MEB que também são imprescindíveis para uma educação popular.

Em primeiro lugar, expusemos um relato no estilo quase de "diário de campo" em que os detalhes do cotidiano dos sujeitos e do seu ambiente são bem descritos nos aspectos culturais, econômicos, políticos e sociais. Isso é resultado da preocupação em realizar uma investigação da realidade em que a equipe atua a fim de alcançar seus objetivos educacionais. Tornase interessante observar ainda que a atividade de supervisão mostra-se mesclada com o estudo de área, o que revela uma presença do princípio de investigação da realidade, em que a "supervisão do ambiente das aulas radiofônicas" não está desintegrada de um contexto social maior. Portanto, a atividade educativa da aula não se encerra em si mesma. O contato empírico com a realidade faz a equipe investigá-la mais, a fim de conhecê-la melhor.

Outro aspecto de destaque é o contato/convivência direta com as bases. Diversas vezes no relato, observa-se a importância dada a tal contato. Daí, certamente, os agentes do MEB iam se assenhoreando da linguagem e dos costumes do povo com quem trabalhava.

A ideia de supletividade está por trás das ações do MEB, a supervisão e o aprofundamento de contato com a comunidade de Agricolândia, visavam, entre outros aspectos, especialmente a "descobrir líderes, tendo em vista o trabalho de animação popular". Ora, desde o início, há uma atenção particular com a continuidade do trabalho pela própria comunidade por meio de seus líderes, o que explicaria a ênfase dada ao contato com os jovens, às visitas, recreações e outras modalidades de interação.

Daí decorre uma pedagogia da não diretividade vista em alguns trechos do relato e traduzida como "um respeito à pessoa e um cuidado extremo para não impor nada"(WANDERLEY, 1984, p. 154): Ao que parece, não 
porque o MEB abdicava da diretividade própria de um processo educativo, mas porque compreendia, à luz dos seus princípios, que o mais importante não era realizar todas as técnicas planejadas e sim auscultar o povo em suas necessidades. Daí surgiriam, criativamente, novas formas de abordagens e novas formas de trabalho com o povo.

A realidade é contradição. Nem sempre a intenção de algo se concretiza de igual forma na realidade da ação desenvolvida. Isso é o que podemos observar em alguns trechos do relato. Em relação a esse fato, gostaria de destacar duas críticas, entre outras, à ação pedagógica da equipe MEB-Piauí. É verdade que, em boa parte, os lapsos dessa ação não são fruto somente dessa equipe, já que a maioria do MEB e dos Movimentos de Educação e Cultura Popular comungava com essa forma de pensar e agir.

O relato apresenta, não obstante preocupação e desvelo em descrever a realidade observada, o modo de olhar, feito a partir de certo modelo de "juventude"e de "família" preestabelecido, o que revela, em alguns momentos, uma considerável distância em relação à realidade descrita na própria narrativa. Os mebianos piauienses relatam que a juventude não tem em que empregar seus momentos de folga. Afirmam que os jovens vivem parados, não se encontram para conversar e divertir-se em um lugar; na mesma sequência, contudo, dizem que a diversão habitual deles são os bailes, as festas, que ocorrem todo sábado, que as aspirações mais fortes da juventude são a recreação e o aprender a ler, mesmo que "não propriamente com fim de cultivar o espírito, mas para poder ler romances populares (de feira) e revistas de aventuras amorosas." Ora, por que afirmar que a juventude é parada, não se encontra, se, na realidade, ela não é parada e se reúne frequentemente? Aqui há claramente o predomínio de um determinado modo de olhar, a partir de um modelo preestabelecido, a ponto de levar as relatoras a negarem tudo o que não esteja contido nele. Não é exagerado supor que esse "modelo de juventude" viciou as narradoras, de forma tal que perceberam suas próprias contradições no relato da realidade observada. Isso também pode ser estendido à questão da família, com tantas outras contradições que podem suscitar considerações similares.

Outro aspecto a ser criticado é a postura de incompreensão e pouca consideração dada pelo MEB às formas de religiosidade popular. Imbuídos de uma formação cristã do catolicismo renovado, vindo, sobretudo de experiências da Ação Católica na JUC, que pregava um catolicismo esclarecido, informado, crítico e teologicamente sistematizado (KADT, 2003), o que, em geral, levava a criticar e ver a religiosidade popular como "certas superstições", 
"conformismo" e"fatalista". Visto sob esse enfoque secularista, a religiosidade popular, certamente, não poderia ser considerada em suas peculiaridades.

O ponto de vista de uma fé europeizada e secularizada desconhece o potencial e a expressão também libertadora/revolucionária da fé popular, como no exemplo dado pela experiência de Canudos e de tantas outras que, por não se enquadrarem nos cânones frios e elitistas "de uma fé esclarecida", inclusive, sob os auspícios "da cientificidade" e das "teorias revolucionárias de um marxismo ortodoxo míope", classificavam a religiosidade popular como "atrasada, arcaica e ópio". Felizmente a experiência posterior da "Igreja Popular" (MAINWARING, 1989) vai mudar de postura diante da religiosidade popular, valorizando-a e reconhecendo a sua legítima expressão (LÖWY, 1990), especialmente nos anos 70, com a disseminação das Comunidades Eclesiais de Base (CEB's).

À guisa de uma conclusão podemos lembrar que o papel do educador/historiador, ao se debruçar sobre o passado-presente, precisa explicitar as sábias e fecundas experiências da Educação Popular, sem esquecer que, situadas num tempo e espaço dados, as significações dessas experiências pervagam o presente ora empobrecidamente, ora com outra quase completa significação; digo, quase, porque somos sempre mescla do "velho e do novo" numa incessante tensão do "devir".

Não obstante a identificação de certas limitações da experiência do MEB-Piauí, a partir do relato de "supervisão e aprofundamento de contato com a comunidade de Agricolândia", constatamos a riqueza contida nele, sobretudo, pela preocupação em transitar nas dimensões macro e micro da realidade onde as equipes atuavam, sem esquecer os sujeitos ali presentes e o esforço de registro do cotidiano. Há implícito nesse procedimento uma pedagogia de investigação da realidade, sem a qual qualquer trabalho de educação popular se descaracteriza por perder uma das suas características básicas: a arte de entregar-se ao intuito de aprender e, simultaneamente, apreender a dinâmica da transitoriedade da realidade.

INNOVATION AND IDEOLOGICAL BIAS OF YOUTH AND ADULT EDUCATION: A HISTORICAL INCURSION FROM A MEB REPORT ON PEDAGOGICAL SUPERVISION

AвSTRACT: The 1960s is undoubtedly a milestone in the History of Youth and Adult Education in Brazil. During this period several education and popular cultural movements were created. Of these, MEB, the grassroots educational movement, is best known and is the only one still in existence. There is a wealth of literature on the movement, although there is little study or research on its presence or performance in the State of Piauí. Certain peculiarities made its performance there somewhat different 
from what is commonly presented in the academic literature. This research, based on primary documental sources, especially from the 1960s, analyzes the practice of the MEB Youth and Adult Education in Piauí, using a report on pedagogical supervision which highlights its innovations and ideological tendencies.

KEYWORDS: Youth and Adult Education. MEB. History of Education. Policy.

\section{REFERÊNCIAS}

DUARTE, Gilberto Pereira. MEB - Teresina: sua história na educação. Teresina(PI), 1973. (mimeo).

FÁVERO, Osmar. Uma Pedagogia de Pparticipação Popular: análise da prática Pedagógica do MEB (1961 a 1966). Tese de Doutorado. São Paulo, PUC, 1984.

KADT, Emanuel de. Católicos radicais no Brasil. João Pessoa: Editora Universitária/ UFPB, 2003. (Edição original em inglês: Catholic Radicals in Brazil. Londres: Oxford University Press, 1970).

LÖWY, Michael. Marxisme et Christianisme em Amérique Latine. In: Revue Tiers-Monde. Tome 31, n. 23, Juillet-Septembre. 1990. p. 667-682.

MAINWARING, Scott. Igreja Católica e política no Brasil (1916-1985). São Paulo: Brasiliense, 1989.

MEB - MOVIMENTO DE EDUCAÇÃO DE BASE. Animação Popular. Rio de Janeiro, 1965. (Apostila 5, série $A$ ).

MEB - MOVIMENTO DE EDUCAÇÃO DE BASE. I Encontro de Coordenadores.1962.

MEB - MOVIMENTO DE EDUCAÇÃO DE BASE. MEB em Cinco anos: 1961-1966. Rio de Janeiro, s.d.

PAIVA, Vanilda. Paulo Freire e o nacionalismo desenvolvimentista. Rio de Janeiro: Civilização Brasileira/Ed. UFC, 1980.

RAPOSO, Maria da Conceição Brenha. OMOVIMENTO DE EDUCAÇÃO DE BASE: Discurso e Prática (1961-1967). São Luís: UFMA/SECRETARIA DE EDUCAÇÃO, 1985.

SEMERARO, Giovanni. A Primavera dos Anos 60: A Geração de Betinho. São Paulo: Centro João XXIII/Loyola, 1994.

SILVA, Santana; GUIMARÃES, Rosa. Relatório de Supervisão e aprofundamento de contato com a Comunidade de Agricolândia. In: MEB -SERPI - Relatório das atividades do Sistema de Escolas Radiofônicas do Piauí. Período de Janeiro a Junho de 1963. Teresina - Piauí, 1963.

SOUZA, Isidoro Pires de. Despontar de Nova Alvorada (Palavras do Coordenador do MEB por ocasião do programa inaugural do MEB). In: MEB -SERPI-Relatório-dezembro de 1961 - março de 1963. Teresina - Piauí, 1962. 
WANDERLEY, Luiz Eduardo W. Educar para transformar: educação popular, Igreja Católica e política no Movimento de Educação de Base. Petrópolis: Vozes, 1984.

Carlos ÂnGelo de Meneses Sousa é professor na Universidade Católica de Brasília e de seu Programa de Pós-Graduação Stricto Sensu em Educação.

E-mail: cangelo@ucb.br 